\title{
Finite Element Analysis of the Delaminated Composite Plates Reinforced by Unidirectional Fibers
}

\section{Milan Žmindák, Pavol Novák, Vladimír Dekýš}

Faculty of applied mechanics University of Žilina, Univerzitná 1, Žilina 010 26, Slovak Republic, E-mail: milan.zmindak@fstroj.uniza.sk, pavol.novak@fstroj.uniza.sk, vladimir.dekys@fstroj.uniza.sk.

Composite materials play an important role in the machine design. Laminated composites have a lot of advantages but in some cases they show different limitations that are caused by stress concentrations between layers. Discontinuous change of material properties is the reason for occurrence of interlaminar stresses that often cause delamination failure. Delaminations in layered plates and beams have been analysed by using both cohesive damage models and fracture mechanics. Modelling of composite structures by finite element (FE) codes to effectively model delamination is limited. Previous efforts to model delamination and debonding failure modes using FE codes have typically relied on ad hoc failure criteria and quasi-static fracture data. Improvements to these modelling procedures can be made by using an approach based on fracture mechanics. This approach allows us to predict the growth of a pre-existing crack or defect. A study of modelling delamination using the FE code ANSYS was conducted.

Keywords: Delamination, Composite, Energy Release Rate, FEM, ANSYS

\section{Acknowledgment}

The authors gratefully acknowledge the support by the Slovak Grant Agency VEGA 1/0983/15 and Slovak Science and Technology Assistance Agency registered under number APVV-0736-12.

\section{References}

[1] CHUNG, D., L., DEBORAH, D., L. (2003). Composite Materials: Functional Materials for Modern Technology, Springer, London.

[2] ZHANG, Z., WANG, S. (2009). Buckling, post-buckling and delamination propagation in debonded composite laminates. Part 1: Theoretical development. In: Composite Struct., Vol. 88, pp. 121-130.

[3] ELMARAKBI, N., HU., FUKUNAGA, H. (2009). Finite element simulation of delamination growth in composite materials using LS-DYNA. In: Composites Sci. Technol., Vol. 69, pp. 2383-2391.

[4] CUI, W., WISNOM, M. A. (1993). Combined stress-based and fracture mechanics-based model for predicting delamination in composites. In: Composites, Vol. 24, pp. 467-474.

[5] SLÁDEK, J., SLÁDEK, V., JAKUBOVIČOVÁ, L. (2002). Application of Boundary Element Methods in Fracture Mechanics, VTS University of Žilina, Žilina.

[6] KORMANIKOVA, E., KOTRASOVA, K. (2014). A damage model for fiber reinforced composite laminate, in: Geoconference on nano, bio and green- technologies for sustainable future (SEG2014), Steff92 Technology Ltd.

[7] AZOUAOUI, K., AZARI, Z., PLUVINAGE, G. (2010). Evaluation of impact fatigue damage in glass/epoxy composite laminate. In: Int. J. Fatigue, Vol. 32, No. 2, pp. 443-452.

[8] MIN WEN, JIXIANG LUO (2016). Study on Mechanical Properties of the Composite Resin Matrix Fiber Reinforced, In: Manufacturing technology, Vol. 15, No. 2, pp. 243-249.

[9] VALÁŠEK, P. (2015). Comparison of variables influence on adhesive bonds strength calculations, In: Manufacturing technology, Vol. 15, No. 3, pp. 205-210.

[10] SOUKUP, J., ŽMINDÁK, M., SKOČILAS, J., RYCHLÍKOVÁ, L. (2014). Application of Mesh-free Methods in Transient Dynamic Analysis of Orthotropic Plates, In: Manufacturing technology, Vol. 14, No. 3, pp. 441-447

[11] ŽMINDÁK, M., PELAGIĆ, Z., SOUKUP, J. (2015). Analysis of Fiber Orientation Influence to Dynamic Properties of Composite Structures. In: Manufacturing technology, Vol. 15, No. 3, pp. 490-494

[12] JIROUTOVA, D. (2016). Methodology of Experimental Analysis of Long-term Monitoring of Sandwich Composite, In: Manufacturing technology, Vol. 16, No. 3, pp. 512-518.

[13] DÁVILA, C., G., CAMANHO, P., P., ROSE, CH., A. (2005). Failure criteria for FRP Laminates. In: J. Composite Mater., Vol. 39, No. 4, pp. 323-345. 
[14] CARRERA, E. (2002). Theories and Finite Elements for Multilayered, Anisotropic, Composite Plates and Shells. In: Arch. Comput. Meth. Eng., Vol. 9, No, 2, pp. 87-140.

[15] REDDY, J., N., MIRAVETE, A. (1995). Practical analysis of composite laminates, CRC Press, New York.

[16] ŽMINDÁK, M., RIECKY, D., DANIŠOVIČ, S. (2010). Finite element implementation of failure and damage models for composite structures. In: Machine Dynamics Res., Vol. 34, No. 1, pp. 130-138.

[17] Ansys v.11, (2207). Theory manual, ANSYS, Inc., Southpointe, PA 2007.

[18] FENSKE, M., T., VIZZINI, A., J. (2001). The inclusion of in-plane stresses in delamination criteria. In: J. Composite Mater., Vol. 35, No. 15, pp. 1325-1342.

[19] BARBERO, E., J. (2008). Finite Element Analysis of Composite Materials, CRC Press, Boca Raton 2008.

\section{Paper number: M201750}

Copyright $\odot$ 2017. Published by Manufacturing Technology. All rights reserved. 